\title{
The revival of the SADC Tribunal by South African courts: A contextual analysis of the decision of the Constitutional Court of South Africa
}

\author{
Moses Retselisitsoe Phooko \\ Dip Human Rights, LLB LLM LLD \\ Associate Professor, Department of Private Law, University of Johannesburg \\ Mkhululi Nyathi \\ LLB LLM LLD \\ Independent Researcher, Bulawayo, Zimbabwe
}

\begin{abstract}
SUMMARY
This article provides a critical analysis of the judgment of the Constitutional Court of South Africa in Law Society of South Africa and Others $v$ President of the Republic of South Africa and Others. ${ }^{1}$ The article analyses the decision and its implications on South African constitutional law and the future conduct of international relations by the South African executive. It further provides a broader legal-historical context of the Southern African Development Community (SADC) decision-making processes and the SADC region's general relationship to the rule of the law. Ultimately, the paper discusses the reasoning of the minority judgment to try to make sense of it.
\end{abstract}

\section{Introduction}

Having been disbanded by the Summit of the Heads of State or Government (Summit) of the Southern African Development Community $(\mathrm{SADC}){ }^{2}$ there is now a possibility, at least in theory, that the SADC Tribunal might be revived. There is also the likelihood that SADC citizens might again have the opportunity to bring their cases, be they of commercial, human rights or of any other nature, to the regional judicial institution when they believe that they have been failed by domestic

1 Law Society of South Africa and Others $v$ President of the Republic of South Africa and Others (CCT67/18) [2018] ZACC 51; 2019 (3) BCLR 329 (CC); 2019 (3) SA 30 (CC).

2 Communique Extraordinary Summit Heads of State and Government of the Southern Africa Development Community Windhoek, Republic of Namibia 20 May 2011 http://www.swradioafrica.com/Documents/SADCSummit24 0511.pdf (accessed 2019-08-20).

How to cite: Phooko \& Nyathi 'The revival of the SADC Tribunal by South African courts: A contextual analysis of the decision of the Constitutional Court of South Africa '2019 De Jure Law Journal 415-432 http://dx.doi.org/10.17159/2225-7160/2019/v52a21 
courts of SADC Member States. ${ }^{3}$ For all this, thanks to the intervention of South Africa's domestic courts. ${ }^{4}$

In a landmark decision that has far reaching implications for South African constitutional law and South Africa's international relations, the South African Constitutional Court has announced, confirming a High Court decision, that the constitutional prescription that the President must always act rationally and lawfully is not only valid in the domestic arena, but follows the President even when conducting international relations. ${ }^{5}$

The case of Law Society of South Africa and Others $v$ President of the Republic of South Africa and Others, ${ }^{6}$ is refreshingly disruptive of the classical view which seem to be still part of the jurisprudence of some constitutional democracies, that give too much deference to the executive when it comes to the conduct of international relations; ${ }^{7}$ where the executive reigns supreme with very limited, if any, judicial and parliamentary oversight.

The Constitutional Court has held that in disbanding the SADC Tribunal and purporting to replace it with a weaker one and doing so contrary to the provisions of the SADC Treaty, the Summit acted unlawfully and irrationally. Consequentially, the South African President's participation in the decision-making processes and his own decisions to suspend the operations of the SADC Tribunal, and his signature on the 2014 Protocol on the Tribunal in the Southern African Development Community (2014 Tribunal Protocol) were, by reason of sections 7(1) and (2) and section 8(1) of the South African Constitution, unconstitutional, unlawful and irrational. ${ }^{8}$ The court then ordered the president to withdraw his signature from the 2014 Tribunal Protocol.

3 Ngatane "Ramaphosa withdraws SA from controversial SADC Tribunal Protocol" https://ewn.co.za/2019/08/18/ramaphosa-withdraws-sa-from-con troversial-sadc-tribunal-protocol (accessed 2019-08-19); Asmeslash "Southern African Development Community (SADC) Tribunal" https:// www.mpi.lu/fileadmin/mpi/medien/research/MPEiPro/2496_Southern African_Development_Community_Tribunal.pdf (accessed 2019-08-19).

4 Law Society of South Africa and Others $v$ President of the Republic of South Africa and Others (CC) supra. Law Society of South Africa and Others $v$ President of the Republic of South Africa and Others (20382/2015) [2018] ZAGPPHC 4; [2018] 2 All SA 806 (GP); 2018 (6) BCLR 695 (GP). See also Ngatane supra; Asmeslash supra; Swart "A house of justice for Africa: Resurrecting the SADC Tribunal" https://www.brookings.edu/blog/africa-infocus/2018/04/02/a-house-of-justice-for-africa-resurrecting-the-sadc-tribun al/ (accessed 2019-08-19).

5 Law Society of South Africa and Others $v$ President of the Republic of South Africa and Others (CC) supra.

6 Law Society of South Africa and Others $v$ President of the Republic of South Africa and Others (CC) supra.

7 See African Peer Review Mechanism Country Review Report No. 8 on The Federal Republic of Nigeria (Review Report is on file with authors).

8 Law Society of South Africa and Others $v$ President of the Republic of South Africa and Others (CC) supra, para 93. 
While remarkable and refreshing, the position taken by the Constitutional Court is not surprising. It resonates with the South African constitutional scheme, both in letter and in spirit. ${ }^{9}$ The President is a public servant who should always act within the prescriptions and proscriptions of the Constitution. ${ }^{10}$ The President does not suddenly mutate into a Leviathan once she/he enters the international relations arena. ${ }^{11}$ In a way, the court's message to the president is that she/he is the torchbearer of the South African constitutional normative values both within and outside the Republic. In the apt words of the court:

“... the President of South Africa] is never at large to do whatever leaders of other nations consider to be in the best interests of our and their nations. She is always to be guided by the Constitution and the law. For she is the nation's constitutional messenger and may only do what would benefit us and project our country in a positive light". ${ }^{12}$

According to the reasoning of the Constitutional Court, while courts should take care not to unnecessarily constrain the President in the exercise of her/his constitutional powers, this deference to the executive in the policy making and implementation arena:

"is not to be understood as an endorsement of, or solicitation for a licence to exercise presidential or executive powers in an unguided or unbridled way, [as all] presidential or executive powers must always be exercised in a way that is consistent with the supreme law of the Republic and its scheme, as well as the spirit, purport and objectives of the Bill of Rights, our domestic legislative and international law objectives."13

In this article, we provide a critical analysis of the majority decision and its implications on South African constitutional law and the future conduct of international relations by the South African executive. We also provide a broader legal-historical context of SADC decision-making processes and the SADC region's general relationship to the rule of the law. We also briefly discuss the reasoning of the minority judgment to try to make sense of it.

9 See inter alia Preamble to the Constitution of the Republic of South Africa, 1996.

10 Economic Freedom Fighters $v$ Speaker of the National Assembly and Others; Democratic Alliance v Speaker of the National Assembly and Others (CCT 143/ 15; CCT 171/15) [2016] ZACC 11; 2016 (5) BCLR 618 (CC); 2016 (3) SA 580 (CC) para 20

11 Glenister $v$ President of the Republic of South Africa and Others (CCT 48/10) [2011] ZACC 6; 2011 (3) SA 347 (CC) 2011 (7) BCLR 651 (CC).

12 Law Society of South Africa and Others $v$ President of the Republic of South Africa and Others (CC) supra, para 89.

13 Law Society of South Africa and Others $v$ President of the Republic of South Africa and Others (CC) supra, para 3. 


\section{Factual and legal background to the Constitutional Court decision}

Much has been written about the ill-fated SADC Tribunal, both in scholarship and in judicial and quasi-judicial decisions. ${ }^{14}$ Furthermore, part of the story has been succinctly and eloquently summarised by the Constitutional Court of South Africa in the case under discussion. ${ }^{15}$ In this article, a broader contextual, factual and legal background to the SADC Tribunal, and how the determination of its fate ended up in South Africa's domestic courts, is set out. This broader legal-historical context focuses not just on the suspension of the SADC Tribunal but also on the subject of SADC's general relationship to the rule of law.

SADC's predecessor, the Frontline States, was mainly concerned with ensuring the end of colonialism and apartheid in Southern Africa. ${ }^{16}$ When the total political liberation of the whole of Southern Africa was on the horizon, focus shifted to regional economic integration and economic independence especially from apartheid South Africa. ${ }^{17}$ This led to the establishment of the Southern African Development Co-ordination Conference (SADCC) in 1980, which was later transformed into a treatybased organisation - the Southern African Development Community in 1992.

The values of democracy, individual human rights and the rule of law were not high on the agenda of the Frontline States and SADCC, unless of course they were directly linked to the liberation of the peoples as a collective. ${ }^{18}$ However, with the winds of democratic change blowing

14 See for example, de Wet "The rise and fall of the Tribunal of the Southern African Development Community: Implications for dispute settlement in Southern Africa" 2013 FILJ 45; Cowell "The death of the Southern African Development Community's human rights jurisdiction” 2013 HRLR 153; Nathan "The disbanding of the SADC Tribunal: A cautionary tale" $2013 H R Q$ 870; Ebobrah "Tackling threats to the existence of the SADC Tribunal: A critique of perilously ambiguous provisions in the SADC Treaty and the Protocol on the Tribunal" 2010 MLJ 199; Ndlovu "Campbell $v$ Republic of Zimbabwe: A moment of truth for the SADC Tribunal" 2011 SADCLJ 63; Mike Campbell (Pvt) Ltd and Others $v$ Republic of Zimbabwe (2/2007) [2008] SADCT 2 (28 November 2008); Mike Campbell (PVT) Limited and Another v Republic of Zimbabwe (2/07) [2007] SADCT 1 (13 December 2007); Luke Munyandu Tembani \& Another $v$ Angola \& 13 Others, African Commission on Human and People's Rights (Communication 409/12); Gramara (Pvt) Ltd $v$ Government of Zimbabwe HC 33/09; Government of the Republic of Zimbabwe $v$ Fick and Others (CCT 101/12) [2013] ZACC 22; 2013 (5) SA 325 (CC); 2013 (10) BCLR 1103 (CC) (27 June 2013).

15 Law Society of South Africa and Others $v$ President of the Republic of South Africa and Others (CC) supra, paras 8-16.

16 The relevant historical material presented here is derived from https:// www.sadc.int/about-sadc/overview/history-and-treaty/\#sadc (accessed 2019-01-18).

17 Saurombe "The role of South Africa in SADC regional integration: The making or breaking of the organization" 2010 JICLT 124.

18 Viljoen International Human Rights Law in Africa (2007) 492. 
across the entire globe from the mid-1980s, the people of Southern Africa were also hungering for democracy, individual human rights and the rule of law. ${ }^{19}$ Unsurprisingly, the 1992 Treaty and the Declaration establishing the Southern African Development Community (the 1992 SADC Treaty) explicitly provided for democracy, human rights and the rule of law as part of the principles of SADC. ${ }^{20}$ Subsequent amendments to the Treaty in 2001 saw the normative value of democracy becoming part of the SADC objectives as well. ${ }^{21}$ The normative values of democracy, human rights and the rule of law also feature prominently in a number of SADC Protocols and policy documents. ${ }^{22}$

In addition to making the normative values of democracy, human rights and the rule of law part of the principles of SADC, and the promotion of democracy part of the objectives of SADC, the SADC Tribunal was established as part of the core institutions of SADC. ${ }^{23}$ In terms of the SADC Treaty, the mandate of the SADC Tribunal is "to ensure adherence to and proper interpretation of the provisions of this Treaty and subsidiary instruments and to adjudicate upon disputes as may be referred to it". 24

However, there was an evident reluctance to operationalise the SADC Tribunal. Instead of setting out in detail the full extent of its jurisdictional competence, composition and other matters in the text of the SADC Treaty itself, these matters were deferred to a Protocol to be adopted later. In 2000, the Protocol on the Tribunal in the Southern African Development Community and Rules thereof (2000 Tribunal Protocol) was adopted; but SADC Member States were reluctant to ratify it so as to operationalise it. It took a SADC Treaty amendment and the amendment of the Protocol itself to remove it from the tentacles of the ratification process and to make it the only Protocol that formed an integral part of the SADC Treaty, subject to the same amendment process as the

19 Lieberman "Organizational cloaking in Southern Africa, South Africa and the SADCC after apartheid transformation http://www.princeton.edu/ esl/ esl/papers_\&_publications_files/Lieberman \% 20Organizational \% 20Cloak ing \% 20in \% 20Southern \% 20Africa.pdf (accessed 2019-08-19).

20 See art 4(c) of the 1992 SADC Treaty.

21 See art 5(1)(b) of the SADC Treaty as amended in 2001. The equivalent provision in the 1992 Treaty did not mention democracy. The Consolidated Text of the Treaty of the Southern African Development Community which incorporates the 2001 and subsequent amendment https://www.sadc.int/ files/5314/4559/5701/Consolidated_Text_of_the_SADC_Treaty___scanned_ 21_October_2015.pdf (accessed 2019-01-18).

22 See for example item 1.5.3 of the SADC Regional Indicative Strategic Development Programme (RISDP) https://www.sadc.int/about-sadc/over view/strategic-pl/regional-indicative-strategic-development-plan/ (accessed 2019-08-19).

23 See article 9 of the Consolidated Text of the SADC Treaty https://www. sadc.int/files/5314/4559/5701/Consolidated_Text_of_the_SADC_Treaty_ scanned_21_October_2015.pdf (accessed 2019-08-19); MR Phooko The SADC Tribunal: its Jurisdiction, Enforcement of its Judgments and the Sovereignty of its Member States (LLD dissertation 2016 UNISA) 9.

24 Art 16(1) of the SADC Treaty. 
Treaty. ${ }^{25}$ Even then, it would take some more years for the judges to be appointed and the Tribunal Registry to be set up and for the Tribunal to start operating in 2007.26 Therefore, while the other SADC institutions got to work immediately, it would take a long 15 years for the SADC Tribunal to be operational. ${ }^{27}$

In terms of design, the 2000 Tribunal Protocol was very progressive: SADC citizens could approach the SADC Tribunal alleging, among other things, violation of the SADC Treaty by a SADC Member State, ${ }^{28}$ but only after exhausting local remedies or proving that local remedies were not available. ${ }^{29}$ In making its determination, the SADC Tribunal had a wide pool of sources of law to draw on - the SADC Treaty; the 2000 Tribunal Protocol; and subsidiary instruments adopted by the Summit, by the Council of Ministers or by any institution or organ of SADC pursuant to the Treaty or protocols. It was also given the power to "develop its own Community jurisprudence having regard to applicable treaties, general principles and rules of international law and principles of the laws of Member States". 30

When it eventually started operating, the SADC Tribunal developed an impressive jurisprudence covering diverse legal fields including labour law, ${ }^{31}$ the law of agency, ${ }^{32}$ and human rights law, ${ }^{33}$ among other areas of law. The Tribunal's progressive and well-reasoned human rights jurisprudence incensed countries with poor human rights records, particularly Zimbabwe. ${ }^{34}$

In one of the first cases before the SADC Tribunal, Mike Campbell (Pvt) Ltd and Others $v$ The Republic of Zimbabwe, ${ }^{35}$ the Tribunal found Zimbabwe's chaotic and violent land reform programme to be contrary to several SADC Treaty provisions. It thereafter ordered the Zimbabwean government to protect the right to property in relation to the farms that had not been expropriated and to pay compensation to those whose

25 Arts 18 and 21 (a) of the 2001 Agreement Amending the Treaty of the Southern African Development Community; Agreement Amending the SADC Tribunal Protocol 2002.

26 Ebobrah "Litigating human rights before sub-regional courts in Africa: Prospects and challenges" 2009 AJICL 83.

27 Nyathi The Southern African Development Community and Law (2019) 67.

28 Art 15(1) of the 2000 Tribunal Protocol.

292000 Tribunal Protocol supra, art 15 (2).

302000 Tribunal Protocol supra, art 21.

31 See for example Ernest Francis Mtingwi v SADC Secretariat SADC (T) 1/2007; Kethusegile-Juru $v$ SADC Parliamentary Forum SADC (T) 02/2009.

32 United People's Party $v$ Southern African Development Community and Others SADC (T) $12 / 2008$.

33 See for example Mike Campbell (Pvt) Ltd and Another $v$ Republic of Zimbabwe SADC (T) 02/2007 supra; Barry L.T. Gondo and 8 Others $v$ the Republic of Zimbabwe SADC (T0 05/2008; Zimbabwe Human Rights NGO Forum $v$ Republic of Zimbabwe SADC (T) 05/2009.

34 Phooko "No longer in suspense: Clarifying the human rights jurisdiction of the SADC Tribunal” 2015 PELJ 556.

35 Mike Campbell (Pvt) Ltd and Others v Republic of Zimbabwe (2/2007) supra. 
farms had been expropriated. ${ }^{36}$ The Zimbabwean government defied this ruling. The noncompliance was referred to the Summit. Compliance with the SADC Tribunal's judgments was not forthcoming on the part of Zimbabwe, even after the successful litigants sought and obtained orders from the Tribunal to enable the SADC Summit to compel compliance by Zimbabwe. ${ }^{37}$

Instead of the SADC Summit acting to ensure that Zimbabwe complied with the SADC Tribunal judgments, it sided with Zimbabwe which had begun a diplomatic attack on the Tribunal employing very weak legal arguments alleging that the SADC Tribunal was not lawfully established owing to the non-ratification of the 2000 Tribunal Protocol. ${ }^{38}$ Furthermore, Zimbabwe claimed that the SADC Tribunal did not have jurisdiction to determine human rights issues. ${ }^{39}$ The Summit eventually decided not to reappoint those Members of the Tribunal (the judges) whose terms of office were ending in 2010 nor replacing those whose term of office would end in 2011. ${ }^{40}$ The Summit also directed the Tribunal not to receive any new cases pending a review of the Tribunal's "terms of reference". 41 These developments effectively meant that the SADC Tribunal was emasculated and could not operate. In the words of one scholar, the Tribunal was 'disbanded'. ${ }^{42}$ All this - the non-renewal of the judges' terms of office (and the non-appointment of their replacements) and the directive not to receive new cases, had no basis in the SADC Treaty and the 2000 Tribunal Protocol, and was therefore unlawful. ${ }^{43}$

Subsequently, the SADC Summit adopted a new Tribunal Protocol in 2014 in violation of clearly set out Treaty procedures. ${ }^{44}$ The 2014 Tribunal Protocol no longer forms an integral part of the SADC Treaty like its "predecessor", and is being subjected to a ratification process which

36 Mike Campbell (Pvt) Ltd and Others v Republic of Zimbabwe (2/2007) supra, para 59

37 Mike Campbell (Pvt) Ltd and Others $v$ the Republic of Zimbabwe SADC (T) 11/ 2008 (18 July 2008); William Michael Campbell and Another $v$ the Republic of Zimbabwe SADC (T) 03/2009 (5 July 2009).

38 Ngandwe "The Predicament of African regional courts: Lessons from the Southern African Development Community Tribunal" 2012 PAYL 54; The Government of the Republic of Zimbabwe v Fick and Others 2013 (5) SA 325 (CC). Phooko (2016) 78, 79.

39 See for example the arguments advanced by Zimbabwe in Government of the Republic of Zimbabwe $v$ Fick and Others (657/11) [2012] ZASCA 122 (20 September 2012) para 10.

40 SADC Summit decision of August 2010.

41 SADC Summit decision of August 2010 supra.

42 Nathan "The disbanding of the SADC Tribunal: A cautionary tale' (2013) 35/ $4 H R Q 870$.

43 See also Tanganyika Law Society and Others $v$ Ministry of Foreign Affairs and International Cooperation of the United Republic of Tanzania Cause No. 23 of 2014 (Judgment delivered on 6 June 2019) (decision on file with authors).

44 Being an integral part of the Treaty, the Summit should have amended both the relevant provisions of the SADC Treaty and those of the 2000 Tribunal Protocol through employing the procedure requiring three quarters of the Members of the Summit. 
means that it might take many years, if at all, for the Tribunal to be reestablished since two thirds of SADC Member States would need to ratify the 2014 Tribunal Protocol for it to come into force. ${ }^{45}$ It also seeks to create a weaker Tribunal that would no longer accept cases from individual SADC citizens. ${ }^{46}$ In addition, its substantive jurisdiction would be very limited and its sources of law reduced to just the SADC Treaty and the applicable SADC Protocol. ${ }^{47}$

An attempt to revive the SADC Tribunal through the African Commission on Human and Peoples' Rights (African Commission) was not successful. ${ }^{48}$ The main argument before the African Commission was that in denying SADC citizens access to the SADC Tribunal, the SADC Heads of State or Government violated binding provisions of the African Charter by, among other things "interfering with the independence, competence and institutional integrity of the SADC Tribunal" and "terminating existing proceedings and vested remedies". 49 The ACHPR rejected this argument and reasoned, quite unsatisfactorily, that the African Charter did not impose any obligation on SADC Member States to guarantee the independence, competence and institutional integrity of the SADC Tribunal. ${ }^{50}$ Further, it held that the African Charter does not create an obligation on SADC Member States to ensure access to the SADC Tribunal. ${ }^{51}$

Some SADC citizens, including those that had approached the African Commission, decided to approach the South African Courts for relief. They lodged their application with the High Court, ${ }^{52}$ which held that the South African President's participation in the processes that led to the disbanding of the SADC Tribunal and the adoption of the 2014 Tribunal Protocol were unconstitutional, unlawful and irrational. Since the declaration of constitutional invalidity needed to be confirmed by the Constitutional Court, the matter ended up at the Constitutional Court, which has confirmed the High Court decision and given an expanded rationale for its decision.

\section{The Constitutional Court judgment}

A preliminary objection was raised that this matter was not ripe for adjudication on the basis that the 2014 Tribunal Protocol was merely

45 Arts $52 \& 53$ of the 2014 Tribunal Protocol.

462014 Tribunal Protocol supra, art 33.

472014 Tribunal Protocol supra, art 35.

48 Luke Munyandu Tembani and Benjamin John Freeth $v$ Angola and Thirteen Others Communication 409/12.

49 Law Society of South Africa and Others $v$ President of the Republic of South Africa and Others (CC) supra, para 115.

50 Law Society of South Africa and Others $v$ President of the Republic of South Africa and Others (CC) supra, para 144.

51 Law Society of South Africa and Others $v$ President of the Republic of South Africa and Others (CC) supra, para 145.

52 Law Society of South Africa and Others $v$ President of the Republic of South Africa and Others (GP) supra. 
signed but not ratified and therefore, the applicants ought to have challenged the President's conduct after ratification. Overall, the respondents were of the view that the President's signature on the 2014 Tribunal Protocol had no force and effect. The court dismissed the preliminary objection as it reasoned that the signing of a treaty by the South African President "creates far-reaching possibilities that could have irreversible consequences". 53

The court in part based its decision dismissing the preliminary objection on an important principle of international law that a party that has signed but not yet ratified a treaty, is under an obligation not to defeat the purposes and objects of that treaty. ${ }^{54}$ Therefore, even if South Africa has merely signed the 2014 Tribunal Protocol but not ratified it, it would still be obliged not to act contrary to the provisions of the 2014 Tribunal Protocol. In other words, South Africa cannot sit back and do nothing when its citizens have no access to courts at a SADC regional level or do something that is contrary to the principles of democracy, human rights and the rule of law.

The main argument advanced by applicants was that the President, through his conduct, acted irrationally, violated human rights, the rule of law, denied South African citizen access to regional justice and acted outside the perimeters of the Constitution. ${ }^{55}$ The respondents argued that the President's signature did not violate the SADC Treaty or the 2000 Tribunal Protocol. Further, they argued that the President's reasons for his signature were explained, and that his signature was not "purposeless, irrational or in bad faith". 56

After considering the conflicting submissions, the court determined that the 2010 and 2011 SADC Summit decisions which resulted in the non-appointment of new judges, refusal to renew the lapsed terms of other judges and the moratorium on the referral of disputes to the SADC Tribunal and the signing of the 2014 Tribunal Protocol essentially destroyed the SADC Tribunal. The Court reasoned as follows:

\footnotetext{
"What the principle of legality entails in the present context is that our President may only exercise power that was lawfully conferred on her and in the manner prescribed. That power must be exercised in good faith and should not be misconstrued. Legality therefore exists to ensure that the repository of public power stays within the vital limits of the power conferred and being exercised. Both Houses of our Parliament resolved, in terms of the predecessor of section 231(2) of our Constitution, to ratify the Treaty. For this reason, no constitutional office-bearer, including our President may act, on behalf of the State, contrary to its provisions. They are all, as agents of the
}

53 Law Society of South Africa and Others $v$ President of the Republic of South Africa and Others (GP) supra, para 48.

54 See article 18 of the Vienna Convention on the Law of the Treaties 1155 UNTS 331, 8 I.L.M. 679, adopted on 23 May 1963 and entered into force on 27 January 1980.

55 Applicant's written submissions paras 20 and 23 (on file with authors).

56 State's written submissions para 4.30 (on file with authors). 
State, under an international law obligation to act in line with its commitments made in terms of that Treaty". 57

The court therefore found no legal basis for the President to have acted contrary to the provisions of a binding Treaty. The court was also alert to the fact that the law required the President to act in line with the dictates of the rule of law as embodied in the Constitution of South Africa. It emphasised that the 2000 Tribunal Protocol could only be amended via a provision of the SADC Treaty, which allows amendments to be made. ${ }^{58}$ According to the court, this could not be done via a protocol such as the 2014 Tribunal Protocol but through the requirement of three-quarters of the SADC Member States. In the words of the court:

"The Summit, however, sought to amend the Treaty through a protocol, thus evading compliance with the Treaty's more rigorous threshold of threequarters of all its Member States. The protocol route would have been an easy way out in that it only requires the support of ten Member States to pass. But, it is not a legally acceptable procedure for stripping the Tribunal of the most important aspect of its jurisdiction." 59

The Constitutional Court therefore found that the decision of SADC Member States "to amend the Treaty through the Protocol evidences a failure to adhere to the provisions or proper meaning of the Treaty". 60 The court concluded that by suspending the SADC Tribunal, the President acted "in a manner that undermined our international law obligations under the Treaty". 61

The court also discussed whether the President acted in good faith when he ignored the prescribed procedure for treaty amendment and opted to sign the 2014 Tribunal Protocol outside the perimeters of the law. The court inter alia concluded that the “... illegality of his conduct also stems from purporting to exercise powers he does not have". 62

Therefore, this rendered the President's conduct unlawful. In light of the previously mentioned considerations, the Constitutional Court confirmed the order of the High Court and ruled that the President's participation in the decision-making process and his own decision to paralyse the SADC Tribunal is unconstitutional, unlawful and irrational. ${ }^{63}$ Additionally, it ruled that the President's signature on the 2014 Tribunal

57 Law Society of South Africa and Others $v$ President of the Republic of South Africa and Others (CC) supra, para 48.

58 Law Society of South Africa and Others $v$ President of the Republic of South Africa and Others (CC) supra.

59 Law Society of South Africa and Others $v$ President of the Republic of South Africa and Others (CC) supra, para 49.

60 Law Society of South Africa and Others $v$ President of the Republic of South Africa and Others (CC) supra, para 50.

61 Law Society of South Africa and Others $v$ President of the Republic of South Africa and Others (CC) supra, para 53.

62 Law Society of South Africa and Others $v$ President of the Republic of South Africa and Others (CC) supra, para 56.

63 Law Society of South Africa and Others $v$ President of the Republic of South Africa and Others (CC) supra. 
Protocol is unconstitutional, unlawful and irrational. Finally, the President was ordered to withdraw his signature from the 2014 Tribunal Protocol.

While reference to the place and value of international law in South Africa and how the former contributed to the attainment of democracy in the latter is prominent in the Constitutional Court decision, ${ }^{64}$ in the main, the decision falls within the realm of South African Constitutional law. First, the president could not act contrary to the provisions of the SADC Treaty, as that would be contrary to the principle of legality. ${ }^{65}$

Second, the Constitutional Court has made it clear that it is the South African Constitution that burdens the office of the President with the requirements of rationality and constitutionality and that these requirements do not fall off the President when she/he acts outside the domestic sphere but they remain attached to her/him as she/he engages in international relations. 66

Third, the normative values embodied in the South African Constitution including democracy, respect for the rule of law and respect for human rights, among others, must find expression in South Africa's relations with foreign states. The relationship between the South African Constitution and international relations has never been expressed in clearer terms. It is not a political policy choice but a constitutional imperative that South African Constitutional values should permeate its international relations. The Constitutional Court spoke plainly on this issue, to wit:

"Our signing of the [2014] Protocol is thus very weighty and significant. It announces to all that South Africa is about to make a radical paradigm shift that is inextricably tied up to who we are as a nation. Specifically, it signifies that access to justice, a commitment to the rule of law and the promotion of human rights would no longer be a paramount feature of our national vision and international relations." ${ }^{\circ 7}$

The court was clear that the matter was not just about respecting the letter and the overall scheme of the South African Constitution, but it was also about projecting a proper constitutional image of South Africa in international relations. According to the court, the Presidents' involvement in the processes that disbanded the SADC Tribunal including the signing of the 2014 Tribunal Protocol conveyed a different message. It could be viewed as indicating that South Africa is no longer interested in the promotion, protection and fulfilment of human rights

64 Law Society of South Africa and Others $v$ President of the Republic of South Africa and Others (CC) supra, paras 4-5.

65 Law Society of South Africa and Others $v$ President of the Republic of South Africa and Others (CC) supra, para 48.

66 Law Society of South Africa and Others $v$ President of the Republic of South Africa and Others (CC) supra, para 75.

67 Law Society of South Africa and Others $v$ President of the Republic of South Africa and Others (CC) supra, para 31. 
and/or honouring obligations flowing from the SADC Treaty and the 2000 Tribunal Protocol. It could also be interpreted as an indication that South Africa is no longer subscribing to issues of access to justice for its citizens at a regional level or that it does not bother whether or not its citizens are ill-treated beyond its borders. In the actual words of the Constitutional Court:

\begin{abstract}
"That signature ... also says to the SADC Member States that South Africa has shorn itself of its key responsibilities of protecting and promoting some of the values foundational to our democracy including fundamental rights. This constitutes a serious threat to the image and very essence of South Africa's constitutional democracy and citizens' rights. Our President's signature is symbolic of a warm welcome by South Africa of the stealthy introduction of impunified disregard for and violation of fundamental rights or key Treaty provisions. It inadvertently but in reality reassures all others that we would turn a blind eye to human rights abuses and non-adherence to the rule of law in their jurisdictions even if it affects our people."68
\end{abstract}

The import of the above dictum is that since South Africa plays an influential role within the SADC region, its withdrawal from key human rights instruments may send a negative message to other countries who generally do not observe the principles of democracy and the rule of law. It is important to highlight that this Constitutional Court decision does not bind other SADC Member States but may serve as a persuasive authority before other domestic courts in other SADC Member States.

\title{
3 The implications of the Constitutional Court decision
}

The Constitutional Court decision has major implications both at the domestic level in the Republic of South Africa and at the SADC region level. First, it has laid down a binding constitutional principle that in engaging in international relations, the president must always be guided by the letter and spirit of the South African Constitution. Executive conduct in the international arena has thus been determined to be reviewable, and the standard for review is the South African Constitution. The Constitutional Court has made it clear that if South Africa is party to an international organisation and that international organisation seeks to promote such normative values as access to justice and the rule of law, among others, the President of South Africa has a duty to protect those normative values as long as they are still part of the South African constitutional scheme. Comity and other considerations that are inimical to the South African constitutional project thus have no place in the conduct of South Africa's international relations.

68 Law Society of South Africa and Others $v$ President of the Republic of South Africa and Others (CC) supra, para 32. 
Going forward, and with respect especially to SADC where democracy and the rule of law appear to be constant challenges, ${ }^{69}$ this means that not only should the President of South Africa be South Africa's constitutional messenger always exuding the South African constitutional spirit, but s/he should always act rationally and legally as if s/he is exercising domestic powers.

It would appear that the Constitutional Court decided to take the opportunity presented by this case to lay the foundation of future jurisprudence in the area of domestic constitutional amendment. In remarks that seem to be obiter dicta but that might have been intended to be seen as deliberate warning shots, the Constitutional Court, although dealing with the amendment of the SADC Treaty, appears to suggest that it would not hesitate to review an amendment of the South African Constitution and that in doing so, it would not confine itself to the procedural aspects of the amendment but would assess the rationality of the amendment. In the words of the Constitutional Court:

"The purpose for the conferment and exercise of the power to amend the Treaty is to do what is in the best interests of the people of SADC. That power is therefore never to be exercised lightly. It is to be exercised in a manner consistent with the seriousness of its consequences to ensure that the invaluable gains and interests of the people of SADC are preserved. The exercise of the power to amend the Treaty must reflect that steps followed in the process leading to the amendment bear a rational relationship with the legitimate purpose for which the power to amend was conferred or exercised." 70

The judgment further states:

"This disregard for the amendment procedure set out in the Treaty and the concomitant failure to appreciate the purpose for the exercise of the power to amend within the context of binding Treaty provisions is irrational and invalidates the President's conduct in relation to the amendment." 71

The above dicta are by no means clear with regard to their import. However, it is difficult to escape the conclusion that the vagueness and lack of elaboration was a deliberate ploy by the court to deftly introduce a principle of rationality in treaty (read constitutional) amendment, which it would be ready to build on once an opportunity presents itself. With the process under way to amend the Constitution of the Republic of South Africa to enable the state to compulsorily acquire land without compensation, which those advocating for the amendment prefer to call a matter of constitutional clarification rather than introducing something new, the possibility of the Constitutional Court interfering with the

69 For a glimpse into the state of democracy and the rule of law in SADC, see generally, Nathan "Solidarity triumphs over democracy - The dissolution of the SADC Tribunal" (2001) DD 123.

70 Law Society of South Africa and Others $v$ President of the Republic of South Africa and Others (CC) supra, para 68.

71 Law Society of South Africa and Others $v$ President of the Republic of South Africa and Others (CC) supra, para 70. 
resultant amendment on the ground of rationality is something to watch out for.

The decision of the Constitutional Court therefore has serious implications for the relationship of South African constitutional law to South Africa's international relations and it also promises to herald new jurisprudence in the area of constitutional amendment.

Beyond the South African domestic realm, the Constitutional Court decision has the potential to affect, in a practical way, the discourse around the SADC Tribunal in the SADC region. The decision disbanding the SADC Tribunal was made by the Summit. The SADC Treaty prescribes the consensus decision method for the taking of decisions by the Summit, ${ }^{72}$ unless there are contrary provisions in the SADC Treaty prescribing a different method. Such contrary provisions apply to the Summit's decision amending the SADC Treaty, which requires a threequarters majority. ${ }^{73}$ The other contrary provision relates to the admission of new Member States into SADC, which requires unanimity. ${ }^{74}$ Had the letter of the SADC Treaty been followed, the decision changing the status of the SADC Tribunal (its jurisdictional competence and other matters) would have been in the form of treaty amendment, requiring a three-quarters majority of SADC Summit Members, although eventually this would have also resulted in the amendment of the 2000 Tribunal Protocol as well, in order to bring it into line with the SADC Treaty. But having followed the wrong procedure in disbanding and purporting to replace the SADC Tribunal by way on an ordinary decision, and employing (presumably) the consensus decision making process; and since the South African President has been ordered to withdraw South's Africa's signature, it follows that there is no longer consensus and those decisions should, on their own basis, wrong as they were, be reversed.

But that is just in theory. It is not easy to predict the reaction of the other Members of the Summit to the South African Constitutional Court decision. What is certain though is that as far-reaching as the Constitutional Court's decision is in South Africa's domestic sphere, it is a different matter at SADC level especially since there does not currently exist a judicial organ within SADC with jurisdiction to deal with that matter. The fate of the SADC Tribunal appears to lie in the unpredictable hands of politics. ${ }^{75}$

The decision of the South African Constitutional Court is therefore significant and welcomed. In compliance with the Court's decision, it has been reported that Mr Ramaphosa, the South African President, "has officially withdrawn South Africa's signature from [the 2014 Tribunal

72 Art 10 (6) of the SADC Treaty.

73 SADC Treaty supra, art 36 (1).

74 SADC Treaty supra, art 8 (4).

75 Cowel "The death of the Southern African Development Community Tribunal's human rights jurisdiction" 2013 HRLR 4. 
Protocol]". 76 The withdrawal took place at the 39th SADC Summit, which took place in Tanzania from 17 to 18 August $2019 .{ }^{77}$ It has furthermore been reported that the Summit "noted the withdrawal of South Africa's signature from the Protocol on the Tribunal in the Southern African Development Community of 2014 in compliance with a Constitutional Court ruling". ${ }^{78}$ Perhaps the Summit is now aware of the legal ramifications arising from South Africa's withdrawal. It can only be hoped, in the absence of corrective measures taken by the Summit itself, that the courts of other SADC Member States and Heads of State will follow the route taken by the South African courts and its Head of State to uphold and respect the rule of law by accepting that the 2014 Tribunal Protocol was adopted outside the perimeters envisaged by the 2000 Tribunal Protocol.

Indeed, since the South African Constitutional Court decision, it appears that the winds of change have begun to blow in the right direction as the Tanzanian High Court also held that:

"The suspension of the operations of the SADC Tribunal; and failure or refusal to appoint Judges contrary to the clear Treaty provisions, was inimical to the Rule of law as a foundational principle inherent to the legitimacy of the Community; and as expressly entrenched in the Treaty."79

The High Court of Tanzania has consequently held that it will adjudicate future disputes arising from the SADC Treaty between individual and legal persons against the Government of Tanzania until the SADC Tribunal has been reinstated. ${ }^{80}$

However, the South African Constitutional Court judgement has some few shortcomings, the most notable of which is its failure to properly capture the correct legal position regarding the amendment of the SADC Treaty. The Constitutional Court appears to suggest that three-quarters of SADC Member States are required to amend the SADC Treaty. ${ }^{81}$ That is not so. While there are provisions to ensure that there is some input from Member States in the process of the amendment of the SADC Treaty, ${ }^{82}$ the ultimate decision to amend the SADC Treaty rests with the SADC

76 Ngatane supra.

77 Communique of the 39th SADC Summit of Heads of State and Government, Julius Nyerere International Convention Centre Car Es Salaam, United Republic of Tanzania 17 - 18 August 2019 https://www.sadc.int/files/1915/ 6614/8772/Communique_of_the_39th_SADC_Summit-English.pdf (accessed 2019-08-19).

78 Communique of the 39th SADC Summit of Heads of State and Government, supra.

79 Tanganyika Law Society and Others $v$ Ministry of Foreign Affairs and International Cooperation of the United Republic of Tanzania supra.

80 Tanganyika Law Society and Others $v$ Ministry of Foreign Affairs and International Cooperation of the United Republic of Tanzania supra.

81 Law Society of South Africa and Others $v$ President of the Republic of South Africa and Others (CC) supra, para 49.

82 SADC Treaty supra, art 36 (2). 
Summit as an institution of SADC. ${ }^{83}$ A member of the SADC Summit, purporting to represent their country's interests, ${ }^{84}$ may propose an amendment of the SADC Treaty triggering a process where the SADC Executive Secretary sends out a notice of amendment to all SADC Member States inviting comments within three months. ${ }^{85}$

With or without any comments, the Summit, qua Summit, can proceed to amend the SADC Treaty and the amendment would become effective if accented to by three-quarters of the Members of the Summit. There is no requirement for ratification by Member States. While each member of the Summit represents their respective Member State, when it comes to the amendment of the SADC Treaty, the involvement of the whole constitutional machinery of each Member State, predicated on the doctrine of separation of powers, is not envisaged as is the case with other regional economic communities, most notably, the East African Community, the Economic Community of West African States and the European Union. ${ }^{86}$

Of course, in some SADC Member States like South Africa, the domestic constitutional imperative is such that the legislature would have to play a role in the ratification of the amendment; ${ }^{87}$ but in terms of the SADC Treaty, the involvement of domestic legislatures in SADC Member States is not a requirement. Therefore, equating three quarters of the members of the Summit to three quarters of the SADC Member States in the context of SADC, and particularly in the context of SADC Treaty amendment, does not reflect the correct legal position. However, this lapse by the Constitutional Court does not affect its overall reasoning.

Finally, and surprisingly, the Constitutional Court, mero motu, decided to engage itself in the discussion of a moot point on the question of the hierarchy between the SADC Tribunal and domestic apex courts. In monologue fashion, the court pointed out:

"A matter of great importance that need only be flagged at this stage is whether the Tribunal has jurisdiction even where national apex courts have pronounced themselves on the same issue between the same parties, which would then elevate it to a super-regional court or whether its jurisdiction is only triggered when a domestic court lacks jurisdiction in a particular matter,

83 SADC Treaty supra, art 10(1).

84 Law Society of South Africa and Others $v$ President of the Republic of South Africa and Others (CC) supra par 66. This is properly captured in the judgement where it is stated: "But the Summit, on behalf of Member States, has the power to amend the Treaty and to even disestablish its institutions".

85 SADC Treaty supra, art 36(2).

86 See art 150 of the Treaty for the establishment of the East African Community; arts $89 \& 90$ of the Revised Treaty of the Economic Community of West African States; art 48 of the Consolidated version of the Treaty on European Union.

87 Sec 231(2) of the Constitution of South Africa, 1996. 
involving alleged violation of treaty provisions" as is the case with Zimbabwe." 88

In our view, this flagging was not necessary. By coming together under a regional integration scheme in the form of SADC, the SADC Member States agreed to be bound by certain principles and objectives at the regional level; and they established several institutions to carry out the regional integration agenda. The SADC Tribunal is one such institution. There does not appear to be any conflict between what the Member States agreed to at the regional level with regard to the hierarchy between the SADC Tribunal and the apex domestic courts of SADC Member States. A holistic reading of the SADC Treaty and the 2000 Tribunal Protocol is clear on the relationship of the SADC Tribunal to domestic courts. ${ }^{89}$

The issue of the hierarchical relationship of the SADC Tribunal to the apex domestic courts of SADC Member States is matter was not before the court and ought to have not been raised. If there is any conflict regarding the hierarchy between the SADC Tribunal and apex national courts of SADC Member States, that is a matter that should be dealt with as and when such a dispute arises. However, as we have already indicated, there is enough clarity on this issue in the SADC Treaty itself and in the 2000 Tribunal Protocol.

\section{The minority decision}

Since the Constitutional Court decision does not in any way dispose of the issue at the regional level, and since there is a possibility that some in the SADC region may appear to be persuaded by the minority opinion, either sincerely or as a matter of political convenience, it is necessary to analyse the minority opinion. It is important to note that the minority agree with the majority on the unconstitutionality, irrationality and unlawfulness of the President's participation (and signature) in the processes that resulted in the suspension of the SADC Tribunal. The minority decision also agrees with the order in the majority judgment. However, they differ with the majority on the basis that " $[\mathrm{t}]$ he majority judgement ... seems to locate the unlawfulness of the President's conduct in international law terms" 90 and they reason that this is a wrong approach since "[t]he President cannot, in this or in any other capacity, directly fall foul of the international law of treaties". 91

The minority judgment is wrong in two respects. First, they fail to appropriately grasp the reasoning of the majority judgment. The majority

88 Law Society of South Africa and Others $v$ President of the Republic of South Africa and Others (CC) supra, para 57.

89 See Arts 15 (1) and (2) and 21 of the 2000 Tribunal Protocol.

90 Law Society of South Africa and Others $v$ President of the Republic of South Africa and Others (CC) supra, para 99.

91 Law Society of South Africa and Others $v$ President of the Republic of South Africa and Others (CC) supra, para 100. 
judgment is firmly anchored in the South African Constitution whose relevance, the majority reason, is not limited to the domestic arena but extends to the executive's conduct of international relations. The matter does not involve state accountability/responsibility at international law. It revolves around acceptable constitutional conduct by the President in the international arena where s/he should act not as a free and unconstrained political agent, but should always be guided by the letter and spirit of the South African Constitution and should also always espouse South Africa's constitutional values. The harder the minority try to distance themselves from the majority on this point, the closer they unwittingly associate themselves with them.

Second, the minority judgment's appreciation of the current state of international law seems faulty. The minority decision espouses the classical international law position, which only viewed states as subjects of international law. ${ }^{92}$ International law has however evolved over time. Individuals, including heads of state, are now also direct subjects of international law and are capable of violating international law. ${ }^{93}$ In the final analysis, the minority judgment was as unnecessary as it is unhelpful. It does not in any way propose a persuasive alternative jurisprudence in that area of the law.

\section{Conclusion}

The decision of the South African Constitutional Court is welcomed as it signals the court's commitment to uphold the principles of democracy, human rights and the rule of law not only in South Africa's domestic arena but also at the international level. It also presents an opportunity for the possible revival of the SADC Tribunal although at the end of the day, the fate of the Tribunal would likely lie in the hands of politics. Overall, this decision is a victory, although it might just be a psychological one, for the human rights movement in South Africa and in the SADC region as far as access to justice at the regional level is concerned. It is hoped that the South African President's withdrawal of South Africa's signature from the 2014 Tribunal Protocol will influence other SADC leaders to reconsider their decisions about reviving the SADC Tribunal. In fact, the Tanzanian High Court has also condemned the Tanzanian government's support to dissolve the Tribunal. ${ }^{94}$ It is likely that with these developments, mobilisation by civil society organisations and other stakeholders in SADC will follow in order to revive the Tribunal.

92 Scheneeberger "Responsibility of the individual under international law" (1946-1947) 35 GLR 481.

93 See, for example, Nwosi Head of State Immunity in International Law (LLD dissertation 2011) 272; The Prosecutor $v$ Charles Taylor Case No SCSL -03-01PT.

94 Tanganyika Law Society and Others $v$ Ministry of Foreign Affairs and International Cooperation of the United Republic of Tanzania, supra. 